\title{
The Analysis of Water Quality Using Canadian Water Quality Index: Green Belt Project/Kerbala-Iraq
}

\author{
Fadhil M. Al-Mohammed ${ }^{1 *}$, Riyadh Jasim Mohammed Al-Saadi ${ }^{2}$, Ali M. Al-Fawzy ${ }^{3}$, Saad H. Mohammed-Ali ${ }^{4}$, \\ Abdul-Khider A. Mutasher ${ }^{1}$, Ali H. Hommadi ${ }^{5}$ \\ ${ }^{1}$ Karbala Technical Institute, Al-Furat Al-Awsat Technical University, Karbala 56001, Iraq \\ ${ }^{2}$ Department of Civil Engineering, College of Engineering, University of Kerbala, Karbala 56001, Iraq \\ ${ }^{3}$ Directorate of Water Resources in Kerbala, State Commission on Operation of Irrigation and Drainage Projects, Ministry of \\ Water Resources, Karbala 56001, Iraq \\ ${ }^{4}$ Water Resources Department, College of Engineering, Al-Mustansiriya University, Baghdad 10052, Iraq \\ ${ }^{5}$ State Commission for Dams and Reservoir, Ministry of Water Resources, Baghdad 10052, Iraq
}

Corresponding Author Email: dr.fadeelmohamad@atu.edu.iq

https://doi.org/10.18280/ijdne.160112

Received: 15 October 2020

Accepted: 6 December 2020

\section{Keywords:}

green belt, groundwater, irrigation, sustainability, water quality index

\begin{abstract}
During the last five decades, a huge amount of water pollutants has been recorded in all water resources around the world. Therefore, the water quality has become an important indicator affecting the vitality and productivity of plants, which requires an effective technique to monitor all these pollutants. The main objective of this study is to assess the validity of groundwater for wells located within the boundaries of the Green Belt area in Karbala city/Iraq for irrigation of palm and olive trees. Whereas, the use of saline groundwater as an alternative to available fresh water will promote the sustainable development of water resources. The technique of Water Quality Index (WQI) is a reliable and widely used tool for assessing water quality for various sources, including groundwater. In this study, the Canadian water quality index (CWQI) model was applied to provide a database for planning and monitoring the quality of groundwater in wells located in the study area. Groundwater samples were taken from these wells and tested to find seven parameters which were; $\mathrm{pH}, \mathrm{CL}, \mathrm{Mg}, \mathrm{HCO}_{3}, \mathrm{EC}, \mathrm{Na}$ and $\mathrm{Ca}$. The CWQI values of groundwater for the studied wells ranged from 30 to 35 . According to the CWQI scale, the groundwater of all wells is classified as poor water. Therefore, the groundwater of all wells in the study area must be treated before it is used for the purpose of irrigation of palm and olive trees. This study concluded that to ensure good irrigation management in the study area, future changes of groundwater in the study area must be monitored.
\end{abstract}

\section{INTRODUCTION}

Water is one of the most important resources and the main nerve for life. Water makes up approximately $70 \%$ of the body weight of almost all living organisms. Water has many resources in nature. One of these resources is groundwater, which is the main resource in some areas, such as deserts. Water is used in many sectors such as irrigation, industry and municipal uses. The irrigation sector consumes up to $80 \%$ of the available water. The continuous and excessive use of available fresh water resources, especially in desert areas or those far from water sources, leads to the emergence of water scarcity problems. Therefore, other sources must be searched for to meet the increasing demand for water. In areas where agricultural activities that use fertilizers and pesticides are active, the quality of groundwater is generally exposed to a great possibility of pollution. Hence, the issue of protecting groundwater from pollution has become of crucial importance [1]. The quality of groundwater depends on the quality of the percolating surface water, the quality of the atmospheric precipitation, and the movement of subsurface water and the associated geochemical processes. Temporal changes in the composition and origin of recharged water, and human and hydrological factors may cause continuous changes in the quality of groundwater. The water quality index WQI is defined as a measure that reflects the combined effect of different water quality parameters [2]. The WQI is calculated from the point of view of the suitability of groundwater for irrigation. WQIs are considered as mathematical tools used to interpret understandable and complex data of water quality by indicating the quality level of water [3]. The assessment of groundwater quality for irrigation purpose usually requires various variables to be determined. Dealing with these variables may cause unclarity in understanding, mostly for persons who have no experience in field of water [4]. Therefore, these variables should be analyzed by some procedures that take into consideration the overall affection of these variables on the quality of water. Nowadays, one of these procedures are WQI that has been widely utilized for the analysis and assessment of water quality. Traditionally, by WQI, all measured data of water quality variables are transformed to a dimensionless value that have a quality scale ranged from lowest poor quality of 0 to highest good quality of $100[5,6]$. There are various forms of WQI applications. The first of them was developed by Horton in 1965 [7]. This form of WQI depends on ten parameters that affect water 
quality. Other forms of WQI that deals with different number of parameters can be found in references [8-20]. One of the efficient and simple procedures of WQI calculations is the Canadian WQI procedure; (CWQI) [18], which was used in this study. It was found that the CWQI could give acceptable results for evaluation of raw water quality [21]. The main objective of the present study is to assess groundwater quality for the Green Belt project, located in south of Kerbala city, based on a new approach by using CWQI.

\section{STUDY AREA}

The study area includes the underground water area located within the Green Belt project GBP, south of Kerbala city, Iraq. The GBP was planted with palm and olive trees. The study area lies between latitudes $32^{\circ} 34^{\prime} \mathrm{N}$ to $32^{\circ} 39^{\prime} \mathrm{N}$ and longitudes $43^{\circ} 56^{\prime} \mathrm{E}$ to $43^{\circ} 59^{\prime} \mathrm{E}$ as shown in Figure 1. Kerbala city is located at central zone of Iraq, about $105 \mathrm{~km}$ south of Baghdad, which is the capital of Iraq. The climate of the study area is under the condition of the western desert, which is characterized by cold in winter with low rainfall and hot and dry in summer. All trees in the GBP were irrigated by using drip irrigation system $[22,23]$. The region is far from the paths of oil pipelines and other leakage. The data were taken over a period of ten months. On the other hand, this period is sufficient to provide useful information to the decision-maker in the field of groundwater use in the study area.

\section{MATERIALS AND METHODS}

The water samples were collected during October 2018 to June 2019 from ten wells. Coordinates of each well location were identified using GPS as shown in Table 1. The distance between each two adjacent wells vary from 0.5 to $2.0 \mathrm{~km}$. Figure 1 shows the geographical location of the study area and the sites of the wells. Each of the groundwater samples were analysed for seven parameters which were; $(\mathrm{pH}),\left(\mathrm{CL}^{-1}\right)$, $\left(\mathrm{Mg}^{+2}\right),\left(\mathrm{HCO}_{3}^{-1}\right),(\mathrm{EC}),\left(\mathrm{Na}^{+1}\right)$, and $\left(\mathrm{Ca}^{+2}\right)$ using standard procedures recommended by APHA [24]. Chemical analysis of the water was carried out at the central laboratory of the agriculture directorate of Kerbala.

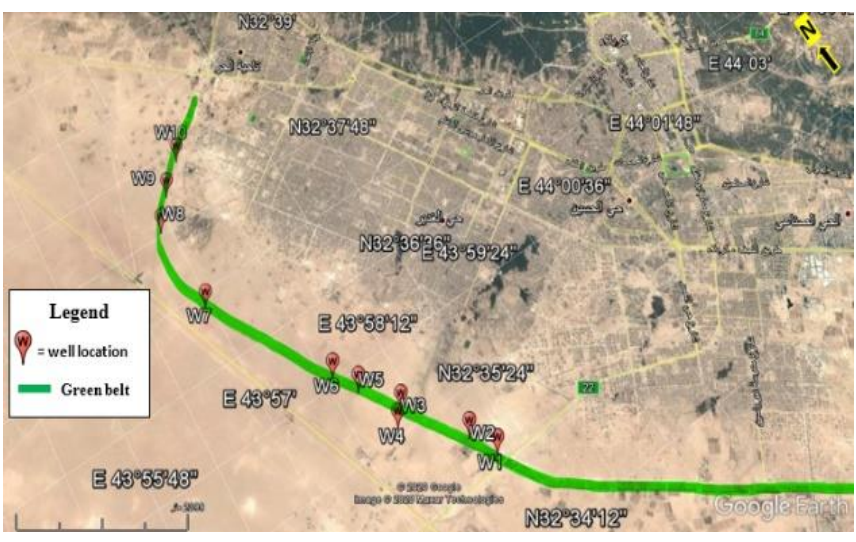

Figure 1. The locations of wells on the green belt project of Kerbala city

\section{WATER QUALITY INDEX}

Water Quality Index, WQI, is an expression that mathematically combines the unique effects of water quality parameters with a single number that is a measure of overall water quality. It is calculated from the point of view of irrigation consumption. Water quality and its suitability for irrigation can be examined by determining its quality index. The objective values of water quality parameters for irrigation purpose (palm and olive trees) as shown in Table 2. have been considered for calculation of WQI. The Canadian water quality index (CWQI) model by Lan \& Long [25] has been used in this study.

Table 1. The locations of the studied wells in UTM and DMS

\begin{tabular}{ccccc}
\hline \multirow{2}{*}{ Well No. } & \multicolumn{2}{c}{ Longitude, E } & \multicolumn{2}{c}{ Latitude, N } \\
\cline { 2 - 5 } & UTME & DMS & UTMN & DMS \\
\hline 1 & 403958 & $43^{\circ} 58^{\prime}$ & 3605322 & $32^{\circ} 34^{\prime}$ \\
& & $36.19^{\prime \prime}$ & & $52.32^{\prime \prime}$ \\
2 & 403746 & $43^{\circ} 58^{\prime}$ & 3605722 & $32^{\circ} 35^{\prime} 5.24^{\prime \prime}$ \\
& & $27.91^{\prime \prime}$ & & \\
3 & 403114 & $43^{\circ} 58^{\prime} 3.36^{\prime \prime}$ & 3606574 & $32^{\circ} 35^{\prime}$ \\
& & & & $32.71^{\prime \prime}$ \\
4 & 402948 & $43^{\circ} 57^{\prime}$ & 3606398 & $32^{\circ} 35^{\prime}$ \\
& & $57.06^{\prime \prime}$ & & $26.95^{\prime \prime}$ \\
5 & 402726 & $43^{\circ} 57^{\prime}$ & 3607128 & $32^{\circ} 35^{\prime}$ \\
& & $48.28^{\prime \prime}$ & & $50.57^{\prime \prime}$ \\
6 & 402503 & $43^{\circ} 57^{\prime}$ & 3607493 & $32^{\circ} 36^{\prime} 2.34^{\prime \prime}$ \\
7 & 401391 & $43^{\circ} 56^{\prime \prime}$ & 3609406 & $32^{\circ} 37^{\prime} 4.12^{\prime \prime}$ \\
& & $56.18^{\prime \prime}$ & & \\
8 & 401342 & $43^{\circ} 56^{\prime}$ & 3610792 & $32^{\circ} 37^{\prime}$ \\
& & $53.77^{\prime \prime}$ & & $49.08^{\prime \prime}$ \\
9 & 401669 & $43^{\circ} 57^{\prime} 6.16^{\prime \prime}$ & 3611241 & $32^{\circ} 38^{\prime} 3.77^{\prime \prime}$ \\
10 & 402062 & $43^{\circ} 57^{\prime}$ & 3611657 & $32^{\circ} 38^{\prime}$ \\
& \multicolumn{5}{c}{$21.10^{\prime \prime}$} & & $17.41^{\prime \prime}$ \\
\hline
\end{tabular}

Table 2. The standard values of water quality parameters for irrigate palm and olive trees

\begin{tabular}{|c|c|c|c|}
\hline \multicolumn{2}{|c|}{ Parameter } & \multirow{2}{*}{$\begin{array}{c}\text { Standard } \\
\text { value }\end{array}$} & \multirow{2}{*}{$\begin{array}{c}\text { Reference } \\
\text { No. }\end{array}$} \\
\hline Symbol & Meaning & & \\
\hline $\begin{array}{c}\mathrm{EC} \\
(\mathrm{dS} / \mathrm{m})\end{array}$ & $\begin{array}{c}\text { Electric } \\
\text { Conductivity }\end{array}$ & 4 & {$[26]$} \\
\hline $\mathrm{pH}$ & Power of Hydrogen & $6.5-8.4$ & [27] \\
\hline SAR & $\begin{array}{c}\text { Sodium Adsorption } \\
\text { Ratio }\end{array}$ & $10-18$ & $\begin{array}{l}{[26] \text { and }} \\
{[28]}\end{array}$ \\
\hline $\mathrm{CL}(\mathrm{mg} / \mathrm{l})$ & Chloride & $100-700$ & $\begin{array}{l}\text { [29] and } \\
\text { [30] }\end{array}$ \\
\hline $\begin{array}{l}\mathrm{HCO}_{3} \\
(\mathrm{mg} / \mathrm{l})\end{array}$ & Bicarbonate & 91.5 & {$[27]$} \\
\hline
\end{tabular}

\section{CALCULATION OF CWQI}

There are two steps to calculating the CWQI. The first step involves identifying the type of water source, the study period, the approved parameters, their standard values, and the objectives of the study. While in the second step, each of the three factors that make up the main structural composition of the index must be calculated. F1 and F2 are computed relatively directly; $\mathrm{F} 3$ requires a few extra steps. The CWQI is determined as below:

1- F1 (Scope); the percentage of parameters that deviates from their standard values; No. of failed parameters, divided by the total number of parameters selected.

$$
\mathrm{F}_{1}=\frac{\mathrm{NFP}}{\mathrm{TNP}} \times 100
$$


where, NFP is number of failed parameters and TNP is total number of parameters.

2- F2 (Frequency) the percentage of individual measurements that deviates from their standard values; No. of failed measurements, divided by the total number of measurements.

$$
\mathrm{F}_{2}=\frac{\mathrm{NFM}}{\mathrm{TNM}} \times 100
$$

where, NFM is number of failed measurements and TNM is total number of measurements.

3- F3 represents the amount by which failed measurements values that deviate from their standard values, F3called also; (amplitude) and can be calculated by the following steps:

Finding the value of term; (Excursion); which represents the number of times by which the measurement value is exceeding the standard value, (or the measurement value is less than the standard value if the standard value is the minimum value). There are two cases in calculating Excursion:

a) When the measurement value must not be greater than the standard value.

$$
\left.\mathrm{EX}_{\mathrm{i}}=\left[\frac{(\mathrm{FMV}}{\mathrm{i})}\right)-1\right)
$$

in which, $\mathrm{EX}_{\mathrm{i}}$ : excursion $\mathrm{i}, \mathrm{FMV}_{\mathrm{i}}$ : failed measurement value $\mathrm{i}$ and SV: standard value.

b) When the measurement value must not be less than the standard value.

$$
\mathrm{EX}_{\mathrm{i}}=\left[\frac{(\mathrm{SV})}{\left(\mathrm{FMV}_{\mathrm{i}}\right)}\right]-1
$$

Normalized sum of Excursions $(\mathrm{N})$ can be calculating by the dividing the summation of excursions on the total number of measurements as follows:

$$
\mathrm{N}=\left[\frac{\left\{\sum_{\mathrm{i}=1}^{\mathrm{n}}\left(\mathrm{EX}_{\mathrm{i}}\right)\right\}}{(\mathrm{TNM})}\right]
$$

The amplitude and CWQI are calculated as follows:

$$
\begin{gathered}
\mathrm{F}_{3}=\frac{\mathrm{N}}{0.01 \mathrm{~N}+0.01} \\
\mathrm{CWQI}=100-\frac{\sqrt{\mathrm{F}_{1}^{2}+\mathrm{F}_{2}^{2}+\mathrm{F}_{3}^{2}}}{1.732}
\end{gathered}
$$

Computed CWQI values are usually classify into five categories as shown in Table 3 [18].

Table 3. Water quality categories assessment scale by (CWQI)

\begin{tabular}{ccc}
\hline Water quality Categories & Classification & $\begin{array}{c}\text { Value of } \\
\text { CWQI }\end{array}$ \\
\hline $\begin{array}{l}\text { Excellent, This range } \\
\text { represents conditions very } \\
\text { close to normal levels, and } \\
\text { there are no indications of } \\
\text { water pollution }\end{array}$ & I & $95-100$ \\
& &
\end{tabular}

Good, The water source needs to be well protects and manages, and conditions

rarely fall outside normal or preferred levels.

Fair, Water quality is usually protected but sometimes threatened; conditions sometimes deviate from normal or preferred levels.

Marginal, Water quality at

the limit point. Frequently threatened or poor; conditions often fall outside normal or preferred levels.

$\underline{\text { Poor, }}$ This range represents levels at which water quality is almost threatened or poor; usually conditions fall outside normal or preferred levels.

\section{RESULTS AND DISCUSSION}

\subsection{Assessment of individual hazard groups}

Concentration of parameters that affect the quality of groundwater used for irrigation purpose depends on the structure of the geological formation of the well region as well as external factors such as agriculture's drainage and other civil operations. All the study wells in this study located in Dibdiba aquifer. Dabdiba formation is an unconfined aquifer; it consists of mainly sandstone with fine gravel, clay siltstone, and silty clay stone. This aquifer was covered with gypsum and sand materials $[22,31,32]$.

\subsubsection{Salinity hazard}

Water salinity risk expressed by electrical conductivity EC are the most important water quality guideline affecting crop growth and productivity. In this study, EXCEL software is used to find the desired statistics of the EV values of water (mean, standard deviation, minimum and maximum) for all studied wells as shown in Table 4. Table 4 illustrates that EC values range from $3.17 \mathrm{dS} / \mathrm{m}$, which was measured in Well 2 in March 2019 to $6.19 \mathrm{dS} / \mathrm{m}$, which was measured in Well 10 in November 2018. Table 4 also shows that the mean EC values for wells No.5 to 10 are greater than that for wells No.1 to 4 , and all mean values of EC are greater than the permissible standard EC value mentioned in Table 2, and therefore, groundwater from all wells is detrimental in direct use for irrigation purposes.

\subsubsection{Sodium hazard}

The risk of sodium is given special attention because of the specific adverse effects of sodium on the physical properties of soil [29]. Sodium risk is usually expressed in the form of the sodium absorption ratio SAR. This index measures the ratio of sodium $(\mathrm{Na})$ to calcium $(\mathrm{Ca})$ and magnesium $(\mathrm{Mg})$ ions in a water sample. High concentrations of sodium in irrigation water can degrade soil structure. This will reduce water infiltration into the soil surface and down the profile, and limit aeration, resulting in reduced crop growth. The SAR is calculated according to Gapon's equation $[33,34]$ as follows: 


$$
\mathrm{SAR}=\frac{\mathrm{Na}^{+}}{\sqrt{\left(\mathrm{Ca}^{++}+\mathrm{Mg}^{++}\right) / 2}}
$$

in which, the concentrations of $\mathrm{Na}, \mathrm{Ca}$ and $\mathrm{Mg}$ are expressed in $(\mathrm{meq} / \mathrm{l})$.

The spatial and temporary values of SAR are presented in Table 5. The values of SAR in the study area ranged from 3.01 for well No.4 (March, 2019) to 19.19 for well No. 7 (June, 2019). Table 5 indicates that the mean values of SAR for wells No. 6, 7, and 8 are within the standard limits of SAR while it is less than the permissible limits for other wells. These results may be attributed to the lack of the natural sodium ions in the soil layers of wells No. (1 to 5), 9, and 10. Generally, the groundwater of all wells is safe from SAR hazard for irrigation purposes.

\subsubsection{Chloride hazard}

Chloride concentrations are presented as the other parameter defining the specific ion toxicity. In this study, EXCEL is used to describe statistic of water chloride concentration (median, standard deviation, minimum and maximum) for all studied wells as shown in Table 6. The chloride concentrations in all wells vary from $495.63 \mathrm{mg} / \mathrm{l}$ measured at well No. 4 in November 2018 to $1949.18 \mathrm{mg} / 1$ measured at well No. 6 in January 2019.

The mean values of CL illustrated that the groundwater of all wells except well No.3 has high average concentration of Chloride. The reason behind this high concentration is due to the nature of the soil and the geological formations of the region in addition to the effect of the drainage of agriculture areas [22, 31]. Hence, the direct use of this water is not acceptable for irrigation purposes

\subsubsection{Bicarbonate hazard}

High bicarbonate concentrations in irrigation water can have harmful effects on plant health [33]. Table 7 shows the results of laboratory measurements of bicarbonate concentration in all water wells in the study area.

The HCO3 concentrations in the groundwater of all wells vary from $40.94 \mathrm{mg} / 1$ measured at well No. 1 in November 2018 to $149.18 \mathrm{mg} / \mathrm{L}$ measured at well No.7 in November 2018. The value of HCO3 in the groundwater of wells No. 1, 4, and 5 is less than the permissible standard value of $91.5 \mathrm{mg} / \mathrm{l}$ while the $\mathrm{HCO} 3$ concentration is greater than its standard value for other wells. As a result, the groundwater of wells No. 1,4 , and 5 is safe from $\mathrm{HCO}_{3}$ hazards, but other wells are not safe.

\subsection{5 pH hazard}

Power of Hydrogen $\mathrm{pH}$ is one of the most important factors that serve as an index for the pollution. The normal $\mathrm{pH}$ range for irrigation water is from 6.5 to 8.4 as shown in Table 2 . EXCEL program was used to describe the statistics of $\mathrm{pH}$ involve median, standard deviation, minimum value, and maximum value for all studied wells as shown in Table 8 .

The value of $\mathrm{pH}$ of the groundwater of wells ranged from 7.13 for well No. 2 at November, 2018 to 8.95 for well No.7 at February, 2019.These results indicate that the ground water tends to be neutralized or little alkaline. The mean observed values of $\mathrm{pH}$ for all wells are within the permissible standard values of $\mathrm{pH}$. Therefore, the groundwater of wells is safe from $\mathrm{pH}$ hazards.

\subsection{Calculating of CWQI}

The previous five parameters, which are sodium absorption ratio, $\mathrm{pH}$, chloride, bicarbonate, and electrical conductivity, were used to calculate the CWQI. The values of parameters F1, F2, F3, and CWQI for groundwater of ten wells are determined by using Eqns. (1) to (6). Table 9 shows the values of these parameters. In addition, Figure 2 shows the calculated values of CWQI for all wells.

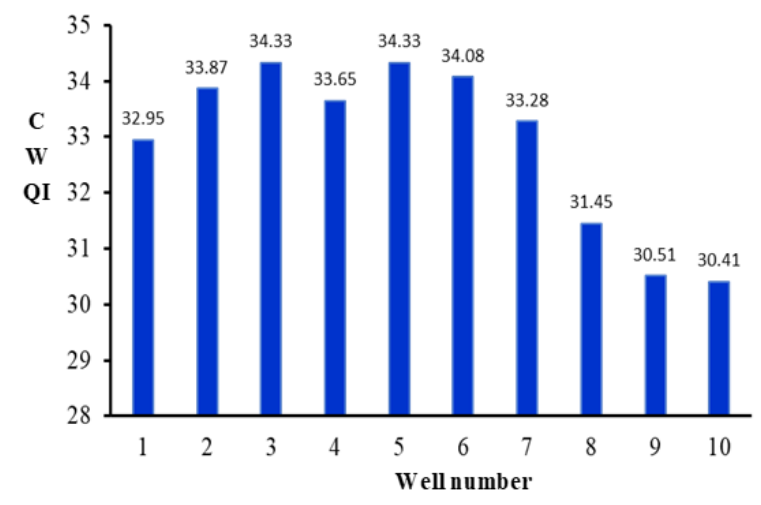

Figure 2. The calculated values of CWQI for the ten wells

Table 4. Monthly measured values of EC with its statistical parameters

\begin{tabular}{|c|c|c|c|c|c|c|c|c|c|c|c|}
\hline \multirow{2}{*}{ Parameter } & \multirow{2}{*}{ Month-Year } & \multicolumn{10}{|c|}{ Well number } \\
\hline & & 1 & 2 & 3 & 4 & 5 & 6 & 7 & 8 & 9 & 10 \\
\hline \multirow{15}{*}{$\mathrm{EC}, \mathrm{dS} / \mathrm{m}$} & October-2018 & 5.14 & 5.06 & 4.61 & 4.29 & 5.72 & 5.18 & 5.01 & 5.72 & 4.67 & 4.39 \\
\hline & November-2018 & 4.92 & 5.94 & 4.93 & 5.03 & 5.31 & 5.37 & 5.89 & 6.02 & 5.81 & 6.19 \\
\hline & December-2018 & 5.85 & 5.81 & 3.72 & 5.81 & 6.01 & 4.17 & 4.47 & 3.92 & 5.31 & 5.28 \\
\hline & January-2019 & 5.01 & 4.06 & 4.67 & 4.35 & 4.35 & 4.92 & 4.59 & 4.78 & 5.04 & 5.19 \\
\hline & February-2019 & 4.27 & 4.62 & 4.37 & 3.86 & 5.85 & 5.58 & 4.06 & 5.73 & 5.48 & 5.62 \\
\hline & March-2019 & 4.74 & 3.17 & 5.21 & 4.83 & 5.93 & 6.03 & 4.28 & 5.1 & 5.93 & 5.61 \\
\hline & April-2019 & 3.79 & 4.96 & 3.89 & 3.99 & 4.88 & 4.87 & 5.81 & 4.83 & 4.72 & 3.87 \\
\hline & May-2019 & 5.38 & 5.74 & 4.29 & 5.86 & 5.72 & 4.38 & 5.26 & 5.38 & 4.29 & 4.92 \\
\hline & June-2019 & 4.01 & 4.38 & 4.28 & 4.73 & 5.68 & 4.49 & 5.77 & 5.87 & 4.77 & 5.66 \\
\hline & \multicolumn{11}{|c|}{ Statistical parameters } \\
\hline & Mean & 4.79 & 4.86 & 4.44 & 4.75 & 5.49 & 5.00 & 5.02 & 5.26 & 5.11 & 5.19 \\
\hline & Standard Deviation & 0.63 & 0.86 & 0.45 & 0.68 & 0.52 & 0.57 & 0.66 & 0.64 & 0.52 & 0.67 \\
\hline & Minimum & 3.79 & 3.17 & 3.72 & 3.86 & 4.35 & 4.17 & 4.06 & 3.92 & 4.29 & 3.87 \\
\hline & Maximum & 5.85 & 5.94 & 5.21 & 5.86 & 6.01 & 6.03 & 5.89 & 6.02 & 5.93 & 6.19 \\
\hline & Median & 4.92 & 4.96 & 4.37 & 4.73 & 5.72 & 4.92 & 5.01 & 5.38 & 5.04 & 5.28 \\
\hline
\end{tabular}


Table 5. Monthly measured values of SAR with its statistical parameters

\begin{tabular}{|c|c|c|c|c|c|c|c|c|c|c|c|}
\hline \multirow{2}{*}{ Parameter } & \multirow{2}{*}{ Month-Year } & \multicolumn{10}{|c|}{ Well number } \\
\hline & & 1 & 2 & 3 & 4 & 5 & 6 & 7 & 8 & 9 & 10 \\
\hline \multirow{15}{*}{$\mathrm{SAR},(\mathrm{meq} / \mathrm{l})^{1 / 2}$} & October-2018 & 4.07 & 6.49 & 4.38 & 3.29 & 4.47 & 14.85 & 16.58 & 6.27 & 9.72 & 5.18 \\
\hline & November-2018 & 5.18 & 4.75 & 4.92 & 4.06 & 3.52 & 5.27 & 17.94 & 11.94 & 6.93 & 7.69 \\
\hline & December-2018 & 3.85 & 5.61 & 6.81 & 4.14 & 3.92 & 12.56 & 17.72 & 13.82 & 9.05 & 6.22 \\
\hline & January-2019 & 3.69 & 6.2 & 6.26 & 4.92 & 4.29 & 15.72 & 10.41 & 10.17 & 7.27 & 8.71 \\
\hline & February-2019 & 4.29 & 5.58 & 4.82 & 3.61 & 4.56 & 8.33 & 16.37 & 8.59 & 10.52 & 5.72 \\
\hline & March-2019 & 5.81 & 4.72 & 6.27 & 3.01 & 4.21 & 14.06 & 17.19 & 7.66 & 9.07 & 9.94 \\
\hline & April-2019 & 5.37 & 5.18 & 6.51 & 3.08 & 5.27 & 14.73 & 17.33 & 11.81 & 10.73 & 5.16 \\
\hline & May-2019 & 4.83 & 4.37 & 4.71 & 4.62 & 5.68 & 18.29 & 18.62 & 9.49 & 11.19 & 10.48 \\
\hline & June-2019 & 4.81 & 5.83 & 5.66 & 4.17 & 5.29 & 17.67 & 19.19 & 10.96 & 10.52 & 8.04 \\
\hline & \multicolumn{11}{|c|}{ Statistical parameters } \\
\hline & Mean & 4.66 & 5.41 & 5.59 & 3.88 & 4.58 & 13.50 & 16.82 & 10.08 & 9.44 & 7.46 \\
\hline & Standard Deviation & 0.69 & 0.67 & 0.85 & 0.64 & 0.67 & 4.00 & 2.42 & 2.22 & 1.43 & 1.89 \\
\hline & Minimum & 3.69 & 4.37 & 4.38 & 3.01 & 3.52 & 5.27 & 10.41 & 6.27 & 6.93 & 5.16 \\
\hline & Maximum & 5.81 & 6.49 & 6.81 & 4.92 & 5.68 & 18.29 & 19.19 & 13.82 & 11.19 & 10.48 \\
\hline & Median & 4.81 & 5.58 & 5.66 & 4.06 & 4.47 & 14.73 & 17.33 & 10.17 & 9.72 & 7.69 \\
\hline
\end{tabular}

Table 6. Monthly measured values of $\mathrm{Cl}$ with its statistical parameters

\begin{tabular}{|c|c|c|c|c|c|c|c|c|c|c|c|}
\hline \multirow{2}{*}{ Parameter } & \multirow{2}{*}{ Month-Year } & \multicolumn{10}{|c|}{ Well number } \\
\hline & & 1 & 2 & 3 & 4 & 5 & 6 & 7 & 8 & 9 & 10 \\
\hline \multirow{15}{*}{$\mathrm{Cl}, \mathrm{mg} / \mathrm{l}$} & October-2018 & 722.69 & 638.95 & 534.92 & 666.21 & 734.72 & 1278.51 & 1907.58 & 1278.45 & 1267.29 & 734.26 \\
\hline & November-2018 & 958.72 & 972.57 & 622.75 & 495.63 & 681.73 & 1728.81 & 1678.95 & 1546.88 & 1363.28 & 974.38 \\
\hline & December-2018 & 793.62 & 928.22 & 601.89 & 633.68 & 917.56 & 983.66 & 1942.58 & 1324.17 & 1298.54 & 683.84 \\
\hline & January-2019 & 920.38 & 698.52 & 555.56 & 918.62 & 902.82 & 1949.18 & 1738.33 & 1578.59 & 1145.69 & 777.36 \\
\hline & February-2019 & 833.28 & 917.63 & 728.94 & 845.72 & 834.71 & 1125.92 & 1589.97 & 1458.19 & 1427.94 & 702.64 \\
\hline & March-2019 & 962.21 & 877.65 & 663.93 & 782,17 & 861.98 & 1469.35 & 1855.38 & 1324.87 & 1458.26 & 792.33 \\
\hline & April-2019 & 967.81 & 638.38 & 514.98 & 961.82 & 1007.62 & 1629.62 & 1648.27 & 1634.88 & 1324.28 & 672.47 \\
\hline & May-2019 & 872.91 & 882.61 & 728.11 & 849.25 & 918.65 & 962.78 & 1758.49 & 1722.54 & 1100.51 & 864.93 \\
\hline & June-2019 & 701.83 & 972.66 & 741.27 & 589.37 & 1218.47 & 1734.83 & 1839.34 & 1289.69 & 1498.62 & 937.28 \\
\hline & \multicolumn{11}{|c|}{ Statistical parameters } \\
\hline & Mean & 859.27 & 836.35 & 632.48 & 745.04 & 897.58 & 1429.18 & 1773.21 & 1462.03 & 1320.49 & 793.28 \\
\hline & Standard Deviation & 96.96 & 130.46 & 82.69 & 159.36 & 146.93 & 337.65 & 114.20 & 156.26 & 127.52 & 103.92 \\
\hline & Minimum & 701.83 & 638.38 & 514.98 & 495.63 & 681.73 & 962.78 & 1589.97 & 1278.45 & 1100.51 & 672.47 \\
\hline & Maximum & 967.81 & 972.66 & 741.27 & 961.82 & 1218.47 & 1949.18 & 1942.58 & 1722.54 & 1498.62 & 974.38 \\
\hline & Median & 872.91 & 882.61 & 622.75 & 755.97 & 902.82 & 1469.35 & 1758.49 & 1458.19 & 1324.28 & 777.36 \\
\hline
\end{tabular}

Table 7. Monthly measured values of $\mathrm{HCO}_{3}$ with its statistical parameters

\begin{tabular}{|c|c|c|c|c|c|c|c|c|c|c|c|}
\hline \multirow{2}{*}{ Parameter } & \multirow{2}{*}{ Month-Year } & \multicolumn{10}{|c|}{ Well number } \\
\hline & & 1 & 2 & 3 & 4 & 5 & 6 & 7 & 8 & 9 & 10 \\
\hline \multirow{15}{*}{$\mathrm{HCO} 3, \mathrm{mg} / \mathrm{l}$} & October-2018 & 53.86 & 61.67 & 51.88 & 61.75 & 102.87 & 84.83 & 121.54 & 116.58 & 126.75 & 145.31 \\
\hline & November-2018 & 40.94 & 82.18 & 73.19 & 86.69 & 87.73 & 78.42 & 159.83 & 137.84 & 137.34 & 125.45 \\
\hline & December-2018 & 113.61 & 69.52 & 123.63 & 78.92 & 84.67 & 93.58 & 117.94 & 111.76 & 96.85 & 137.95 \\
\hline & January-2019 & 74.94 & 79.25 & 84.92 & 84.89 & 91.45 & 136.74 & 145.81 & 142.89 & 122.65 & 121.63 \\
\hline & February-2019 & 96.81 & 100.87 & 93.76 & 91.53 & 73.18 & 111.94 & 132.93 & 100.63 & 116.39 & 110.34 \\
\hline & March-2019 & 118.25 & 123.63 & 96.82 & 64.95 & 67.34 & 127.83 & 128.74 & 127.85 & 148.45 & 132.98 \\
\hline & April-2019 & 84.17 & 96.72 & 84.89 & 98.45 & 81.56 & 151.36 & 116.95 & 136.95 & 120.92 & 100.84 \\
\hline & May-2019 & 63.83 & 117.65 & 131.57 & 103.84 & 72.16 & 98.42 & 120.07 & 131.27 & 137.46 & 94.33 \\
\hline & June-2019 & 101.49 & 120.33 & 116.37 & 68.53 & 81.37 & 140.73 & 131.89 & 120.11 & 91.89 & 106.65 \\
\hline & \multicolumn{11}{|c|}{$\begin{array}{l}110.3708 .53 \quad 81.5 / \\
\text { Statistical parameters }\end{array}$} \\
\hline & Mean & 83.10 & 94.65 & 95.23 & 82.17 & 82.48 & 113.76 & 130.63 & 125.10 & 122.08 & 119.50 \\
\hline & Standard Deviation & 25.31 & 21.56 & 23.94 & 13.98 & 10.29 & 24.94 & 13.48 & 13.08 & 17.54 & 16.53 \\
\hline & MINIMUM & 40.94 & 61.67 & 51.88 & 61.75 & 67.34 & 78.42 & 116.95 & 100.63 & 91.89 & 94.33 \\
\hline & MAXIMUM & 118.25 & 123.63 & 131.57 & 103.84 & 102.87 & 151.36 & 159.83 & 142.89 & 148.45 & 145.31 \\
\hline & MEDIAN & 84.17 & 96.72 & 93.76 & 84.89 & 81.56 & 111.94 & 128.74 & 127.85 & 122.65 & 121.63 \\
\hline
\end{tabular}

Table 10 shows that the CWQI of the groundwater of all wells falls in class (V) (Poor Water). The prime cause of deterioration of the groundwater quality is the high values of $\mathrm{EC}$ and concentrations of $\mathrm{Cl}$ in the groundwater of wells. Previous studies showed that the movement direction of groundwater flow to the study area in from west to east and from southeast to northeast $[11,12]$. This movement leads to increased pollution of groundwater due to dissolution of rocks with various chemical composition during the distance travelled until reaching to the locations of the studied wells. The other reason for the decline in the water quality index values and the deterioration of its quality is the continuous water withdrawal that must be provided to meet the water requirements for irrigation of palm and olive trees in the GBP. 
Table 8. Monthly measured values of $\mathrm{pH}$ with its statistical parameters

\begin{tabular}{cccccccccccc}
\hline \multirow{2}{*}{ Parameter } & \multirow{2}{*}{ Month-Year } & \multicolumn{10}{c}{ Well number } \\
\cline { 5 - 12 } & & 1 & 2 & 3 & 4 & 5 & 6 & 7 & 8 & 9 & 10 \\
& October-2018 & 7.32 & 8.38 & 8.72 & 8.32 & 7.56 & 8.18 & 7.64 & 8.44 & 7.15 & 7.58 \\
& November-2018 & 8.34 & 7.13 & 7.98 & 8.56 & 7.33 & 7.54 & 7.84 & 8.53 & 8.83 & 8.46 \\
& December-2018 & 7.58 & 7.73 & 7.42 & 8.38 & 7.97 & 7.29 & 8.33 & 7.94 & 8.24 & 8.94 \\
& January-2019 & 7.93 & 7.94 & 7.38 & 8.37 & 7.34 & 7.84 & 8.16 & 7.37 & 8.45 & 8.37 \\
& February-2019 & 7.83 & 8.53 & 7.17 & 8.51 & 8.13 & 7.45 & 8.95 & 7.83 & 8.91 & 7.94 \\
& March-2019 & 8.52 & 8.39 & 7.47 & 7.59 & 8.32 & 7.88 & 8.48 & 7.57 & 7.56 & 8.54 \\
& April-2019 & 7.19 & 7.93 & 8.63 & 7.42 & 7.52 & 8.19 & 8.34 & 8.94 & 8.34 & 7.76 \\
$\mathrm{pH}$ & May-2019 & 7.61 & 8.53 & 8.93 & 8.53 & 8.47 & 8.63 & 8.24 & 7.45 & 8.94 & 7.82 \\
& June-2019 & 8.37 & 7.91 & 8.16 & 8.32 & 8.81 & 8.39 & 7.48 & 7.86 & 8.41 & 8.48 \\
& & & \multicolumn{10}{c}{ Statistical parameters } & & & & & \\
& Mean & 7.85 & 8.05 & 7.98 & 8.22 & 7.94 & 7.93 & 8.16 & 7.99 & 8.31 & 8.21 \\
& Standard Deviation & 0.45 & 0.43 & 0.62 & 0.39 & 0.50 & 0.43 & 0.43 & 0.50 & 0.57 & 0.43 \\
& MINIMUM & 7.19 & 7.13 & 7.17 & 7.42 & 7.33 & 7.29 & 7.48 & 7.37 & 7.15 & 7.58 \\
& MAXIMUM & 8.52 & 8.53 & 8.93 & 8.56 & 8.81 & 8.63 & 8.95 & 8.94 & 8.94 & 8.94 \\
& MEDIAN & 7.83 & 7.94 & 7.98 & 8.37 & 7.97 & 7.88 & 8.24 & 7.86 & 8.41 & 8.37 \\
\hline
\end{tabular}

Table 9. The calculations of CWQI

\begin{tabular}{|c|c|c|c|c|c|c|c|c|c|c|}
\hline Well no. & 1 & 2 & 3 & 4 & 5 & 6 & 7 & 8 & 9 & 10 \\
\hline No. of failed parameters & 5 & 5 & 5 & 5 & 5 & 5 & 5 & 5 & 5 & 5 \\
\hline $\mathrm{F} 1$ & 100 & 100 & 100 & 100 & 100 & 100 & 100 & 100 & 100 & 100 \\
\hline No. of failed measurements & 24 & 23 & 23 & 22 & 21 & 22 & 22 & 26 & 28 & 29 \\
\hline F2 & 53.33 & 51.11 & 51.11 & 48.89 & 46.67 & 48.89 & 48.89 & 57.78 & 62.22 & 64.44 \\
\hline $\begin{array}{l}\text { the normalized sum of } \\
\text { excursions }(\mathrm{N})\end{array}$ & 0.34 & 0.29 & 0.22 & 0.4 & 0.38 & 0.34 & 0.45 & 0.38 & 0.33 & 0.24 \\
\hline F3 & 25.37 & 22.48 & 18.03 & 28.57 & 27.54 & 25.37 & 31.03 & 27.54 & 24.81 & 19.35 \\
\hline CWQI & 32.95 & 33.87 & 34.33 & 33.65 & 34.33 & 34.08 & 33.28 & 31.45 & 30.51 & 30.41 \\
\hline
\end{tabular}

The nearest water source to GBP area is about $30 \mathrm{~km}$ away from it. The decision to use the water from that source will lead to great economic costs represented in constructing a water transmission network in addition to equipping the pumping station.

Therefore, it is preferable to use the on-site irrigation source represented by ground water, after conducting the necessary treatments to ensure that the soil and plants are not affected. Whereas, the use of non-conventional salt water after treatment contributes to saving fresh water and achieving the sustainability of water resources.

Table 10. CWQI of the groundwater of all wells with classification

\begin{tabular}{cccc}
\hline $\begin{array}{c}\text { Well } \\
\text { Number }\end{array}$ & $\begin{array}{c}\text { CCME WQI } \\
\text { value }\end{array}$ & $\begin{array}{c}\text { Water quality } \\
\text { rank }\end{array}$ & Classification \\
\hline 1 & 32.95 & Poor & V \\
2 & 33.87 & Poor & V \\
3 & 34.33 & Poor & V \\
4 & 33.65 & Poor & V \\
5 & 34.33 & Poor & V \\
6 & 34.08 & Poor & V \\
7 & 33.28 & Poor & V \\
8 & 31.45 & Poor & V \\
9 & 30.51 & Poor & V \\
10 & 30.41 & Poor & V \\
\hline
\end{tabular}

Compared with the results Abd et al. [35], the researcher used the irrigation water quality index model for same study area. He concluded that $66 \%$ of well water in used under the condition of high restrictions. This is consistent with the results of the present study, which relied on data collected in 2019.

\section{CONCLUSIONS}

This study evaluated the quality of groundwater in the GBP of Karbala, using the Canadian Water Quality Index CWQI. Based on the values of the water quality index obtained, the following conclusions were achieved:

1. The value of CWQI for all wells falls in class (V) (Poor Water) within the range between 30 and 35, and the groundwater of all wells is not suitable to direct use for irrigation purposes in GBP.

2. Plan should be developed to monitor future change to the groundwater quality of GBP area and observe the impact of continuous withdrawal of groundwater on the degree of contamination for water and soil.

3. From the CWQI values, it can be suggested that the groundwater of the studied wells needs additional measures to improve its quality for use in irrigation purposes.

4. It is preferable to use the on-site irrigation source represented by ground water in GBR area, after conducting the necessary treatments to ensure that the soil and plants are not affected. This measure contributes to saving fresh water and achieving the sustainability of water resources.

\section{REFERENCES}

[1] Buselli, G., Lu, K. (2001). Groundwater contamination monitoring with multichannel electrical and electromagnetic methods. Journal of Applied Geophysics, 48(1): 11-23. http://dx.doi.org/10.1016/S0926-9851(01)00055-6 
[2] Ramakrishnaiah, C.R., Sadashivaiah, C., Ranganna, G. (2009). Assessment of water quality index for the groundwater in Tumkur Taluk, Karnataka State, India. EJournal of Chemistry, 6(2): 523-530. http://dx.doi.org/10.1155/2009/757424

[3] Srivastava, G., Kumar, P. (2013). Water quality index with missing parameters. International Journal of research in Engineering and Technology, 2(4): 609-614. http://dx.doi.org/10.15623/ijret.2013.0204035

[4] Pesce, S.F., Wunderlin, D.A. (2000). Use of water quality indices to verify the impact of Córdoba City (Argentina) on Suquía River. Water Research, 34(11): 2915-2926. https://doi.org/10.1016/S00431354(00)00036-1

[5] Lumb, A., Sharma, T.C., Bibeault, J.F. (2011). A review of genesis and evolution of water quality index (WQI) and some future directions. Water Quality, Exposure and Health, 3(1): 11-24. http://dx.doi.org/10.1007/s12403011-0040-0

[6] Massoud, M.A. (2012). Assessment of water quality along a recreational section of the Damour River in Lebanon using the water quality index. Environmental Monitoring and Assessment, 184(7): 4151-4160. http://dx.doi.org/10.1007/s10661-011-2251-z

[7] Tyagi, S., Sharma, B., Singh, P., Dobhal, R. (2013). Water quality assessment in terms of water quality index. American Journal of Water Resources, 1(3): 34-38 http://dx.doi.org/10.12691/ajwr-1-3-3

[8] Mehr, A.D., Nourani, V., Kahya, E., Hrnjica, B., Sattar, A.M., Yaseen, Z.M. (2018). Genetic programming in water resources engineering: A state-of-the-art review. Journal of Hydrology, 566: 643-667. https://doi.org/10.1016/j.jhydrol.2018.09.043

[9] Kükrer, S., Mutlu, E. (2019). Assessment of surface water quality using water quality index and multivariate statistical analyses in Saraydüzü Dam Lake, Turkey. Environmental Monitoring and Assessment, 191(2): 71 https://doi.org/10.1007/s10661-019-7197-6

[10] Singh, S., Hussian, A. (2016). Water quality index development for groundwater quality assessment of Greater Noida sub-basin, Uttar Pradesh, India. Cogent Engineering, $\quad 3(1)$ : 1177155. https://doi.org/10.1080/23311916.2016.1177155

[11] Banda, T.D., Kumarasamy, M.V. (2020). Development of water quality indices (WQIs): A Review. Polish Journal of Environmental Studies, 29(3): 2011-2021. https://doi.org/10.15244/pjoes/110526

[12] Eslami, F., Shokoohi, R., Mazloomi, S., Darvish Motevalli, M., Salari, M. (2017). Evaluation of water quality index (WQI) of groundwater supplies in Kerman Province in 2015. Occupational and Environmental Health, 3(1): 48-58.

[13] Dascalescu, I.G., Morosanu, I., Ungureanu, F., Musteret, C.P., Minea, M., Teodosiu, C. (2017). Development of a versatile water quality index for water supply applications. Environmental Engineering and Management Journal, 16(3): 525-534. https://doi.org/10.30638/eemj.2017.053

[14] Mukherjee, A., Sen, S., Paul, S.K. (2017). A deviation from standard quality approach for characterisation of surface water quality. International Journal of Sustainable Development and Planning, 12(1): 30-41. https://doi.org/10.2495/SDP-V12-N1-30-41

[15] Ismail, A.H., Robescu, D. (2019). Assessment of water quality of the danube river using water quality indices technique. Environmental Engineering and Management Journal, $\quad 18(8)$ : https://doi.org/10.30638/eemj.2019.163

[16] Mutasher, A.A. (2013). Assessment of water quality of al-Husseinieh river/Karbala governorate/Iraq for irrigation purpose by using water quality index ${ }^{+}$. ALTaqani, 26(5): E1-E15.

[17] Cude, C.G. (2001). Oregon water quality index a tool for evaluating water quality management effectiveness 1 . JAWRA Journal of the American Water Resources Association, $37(1)$ : 125-137. http://dx.doi.org/10.1111/j.1752-1688.2001.tb05480.x

[18] Canadian Council of Ministers of the Environment. (2001). Canadian water quality guidelines for the protection of aquatic life. CCME Water QUALITY INDEX 1.0 User's Manual.

[19] Sargaonkar, A., Deshpande, V. (2003). Development of an overall index of pollution for surface water based on a general classification scheme in Indian context. Environmental Monitoring and Assessment, 89(1): 4367. https://doi.org/10.1023/A:1025886025137

[20] Boyacioglu, H. (2007). Development of a water quality index based on a European classification scheme. Water SA, 33(1): 101-106. http://dx.doi.org/10.4314/wsa.v33i1.47882

[21] Ismail, A.H., Robescu, D., Hameed, M.A. (2018). Application of CCME WQI in the assessment of the water quality of Danube River, Romania. Engineering and Technology Journal, 36(2 Part (C)): 142-146. https://doi.org/10.30684/etj.36.2C.8

[22] Al-Mohammed, F.M., Mutasher, A.A. (2013). Application of water quality index for evaluation of groundwater quality for drinking purpose in Dibdiba aquifer, Kerbala city, Iraq. Journal of University of Babylon, 21(5): 1647-1660.

[23] Al-Mohammed, F.M., Mutasher, A.A. (2016). Qualitative assessment of treated wastewater for Irrigation Purpose in Al-Hindiyah district / Karbala City / Iraq. Wasit Journal of Engineering Science, 4(2): 126150.

[24] Baird, R.B., Eaton, A.D., Rice, E.W., Bridgewater, L. (2017). Standard Methods for the Examination of Water and Wastewater. Washington, DC: American Public Health Association.

[25] Lan, T.T., Long, N.P. (2011). Assessment of surface water quality by water quality index (WQI) at the Cai Sao canal, An Giang province, Vietnam. Livestock Research for Rural Development, 23(7): 151.

[26] Fipps, G. (2003). Irrigation water quality standards and salinity management. Texas FARMER Collection, 3-18.

[27] Akter, T., Islam, M.K., Islam, M.M.S., Monirul, M. (2019). Irrigation water quality assessment of Betagi Upazila under Barguna district in Bangladesh. Archives of Agriculture and Environmental Science, 4(4): 428-433 https://doi.org/10.26832/24566632.2019.040409

[28] Flower Association of Queensland Inc (FAQI), Rural Industries Research and Development Corporation, 2013. "Wildflower Irrigation Handbook", ISBN 978-1-74254370-3.

[29] Bauder, T.A., Waskom, R.M., Davis, J.G. (2010). Irrigation Water Quality Criteria. Colorado State University Extension.

[30] Saskatchewan Environment Drinking Water Quality 
Section (2006). "Surface water quality objectives": Interim Edition $\quad$ EFB 356 at http://www.se.gov.sk.ca/environment/protection/waters urface.asp

[31] Al-Jiburi, H.K., Al-Basrawi, N.H., Ibrahim, S.A.R (2002). Hydrogeological and Hydrochemical Study of Karbala Quadrangle (NI-38-14), Scale 1:250000. GEOSURV, Internal Report No. 2825.

[32] Al-Kubaisi, Q.Y., Al-Abadi, A.M., Al-Ghanimy, M.A. (2018). Mapping groundwater quality Index for irrigation in the Dibdibba aquifer at Karbala-Najaf plateau, central of Iraq. Iraqi Journal of Science, 59(3): 1636-1652. https://doi.org/10.24996/ijs.2018.59.3C.10

[33] Kaletová, T., Jurík, L'. (2018). Quality of water required for irrigation. In: Negm A., Zeleňáková M. (eds) Water Resources in Slovakia: Part I. The Handbook of Environmental Chemistry, vol 69. Springer, Cham. https://doi.org/10.1007/698_2017_214

[34] Bhat, M. A., Wani, S. A., Singh, V. K., Sahoo, J., Tomar, D., \& Sanswal, R. (2018). An overview of the assessment of groundwater quality for irrigation. Journal of Agricultural Science and Food Research, 9(1): 1000209.

[35] Abd, M.M., Al-Rahami, K.M., Al-Mohammed, F.M. (2018). Assessment of irrigation water quality for Dabdaba formation by using GIS techniques in Karbala Province, Iraq. Indian Journal of Natural Sciences, 9(50): $14677-14684$.
NOMENCLATURE

$\begin{array}{ll}\mathrm{Ca}^{+2} & \text { Calsium mg. } l^{-1} \\ \mathrm{CL}^{-1} & \text { Chloride m. } .^{-1} \\ \mathrm{EC} & \text { Electric Conductivity Ds.m } \\ \mathrm{F} & \text { Scope (Dimensionless Parameter) } \\ \mathrm{F}_{2} & \text { Frequency (Dimensionless Parameter) } \\ \mathrm{F}_{3} & \text { Amplitude (Dimensionless Parameter) } \\ \mathrm{HCO}_{3}{ }^{-1} & \text { Bicarbonate mg. } .^{-1} \\ \mathrm{Mg}^{+2} & \text { Magnisium mg. } .^{-1} \\ \mathrm{Na}^{+1} & \text { Sodium mg. } \mathrm{l}^{-1}\end{array}$

\section{Subscripts}

CWQI Canadian Water Quality Index

$\mathrm{EX}_{\mathrm{i}}$

$\mathrm{FMV}_{\mathrm{i}}$

NFM

NFP

$\mathrm{N}$

$\mathrm{pH}$

SAR

SV

TNM

TNP

Excursion i

Failed Measurement Value i

Number of Failed Measurements

Number of Failed Parameters

Normalized sum of Excursions

Power of Hydrogen

Sodium Adsorption Ratio

Standard Value

Total Number of Measurements

WQI
Total Number of Parameters

water quality index 